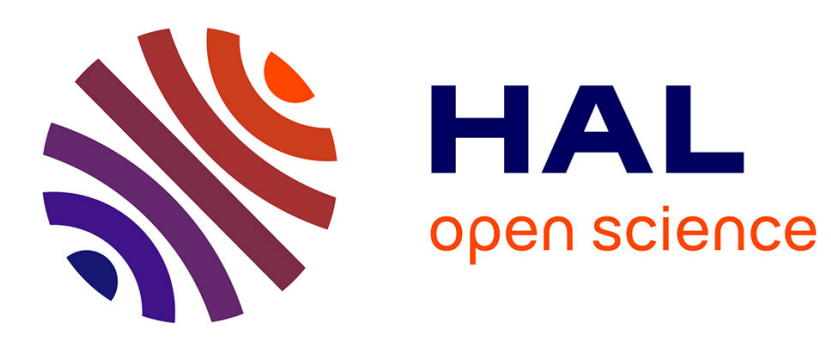

\title{
Is a progressive recruitment of muscle fibers required for the development of the slow component of VO2 kinetics?
}

\author{
F. Borrani, D. Malatesta, Robin Candau
}

\section{To cite this version:}

F. Borrani, D. Malatesta, Robin Candau. Is a progressive recruitment of muscle fibers required for the development of the slow component of VO2 kinetics?. Journal of Applied Physiology, 2009, 106 (2), pp.746. 10.1152/japplphysiol.91336.2008 . hal-02665156

\section{HAL Id: hal-02665156 \\ https://hal.inrae.fr/hal-02665156}

Submitted on 31 May 2020

HAL is a multi-disciplinary open access archive for the deposit and dissemination of scientific research documents, whether they are published or not. The documents may come from teaching and research institutions in France or abroad, or from public or private research centers.
L'archive ouverte pluridisciplinaire HAL, est destinée au dépôt et à la diffusion de documents scientifiques de niveau recherche, publiés ou non, émanant des établissements d'enseignement et de recherche français ou étrangers, des laboratoires publics ou privés. 


\title{
Is a progressive recruitment of muscle fibers required for the development of the slow component of $\dot{\mathrm{V}}_{2}$ kinetics?
}

\author{
F. Borrani, ${ }^{1}$ D. Malatesta, ${ }^{2}$ and R. Candau ${ }^{3}$ \\ ${ }^{1}$ Department of Sport and Exercise Science, University of Auckland, New Zealand; ${ }^{2}$ Institute of Sport Sciences and Physical \\ Education, University of Lausanne, Switzerland; ${ }^{3} U M R$ 866, Différenciation Cellulaire et Croissance, Institut National de la \\ Recherche Agronomique, University of Montpellier 1, France
}

TO THE EDITOR: Zoladz et al. (6) present a reanalysis of data taken from their previous study (3) and they evaluated the oxygen uptake $\left(\mathrm{V}_{\mathrm{O}_{2}}\right)$ response in isolated dog gastrocnemius in situ during 4-min of contractions at $\sim 60-70 \%$ of peak $\dot{\mathrm{V}}_{2}$. In their preparation, all muscle fibers were activated by a supraelectrical stimulation from the beginning of the contraction period, and no progressive recruitment of fibers was possible. The authors reported a $\dot{\mathrm{V}}_{2}$ slow component, defined as "slow component-like," after $\dot{\mathrm{V}}_{2}$ data were normalized per unit of produced force. They concluded that a putative mechanism responsible for the slow component is not necessarily related to a progressive recruitment of muscle fibers. In our opinion, this interpretation seems questionable.

Figure 3 of Zoladz et al. (6) shows a $\dot{\mathrm{V}}_{2}$ stable with a concomitant decrease in force production. What is the meaning of a stable oxygen uptake with a concomitant decrease in force production, when the whole muscle is activated with a maximal stimulation? It means that the fatigue, probably caused by metabolic factors, decreases the efficiency of muscle contractions. Let us consider a few comments.

At least three main hypotheses could be mentioned. Briefly:

1) A reduction of ATP production per mole of oxygen $\left(\mathrm{P} / \mathrm{O}_{2}\right.$ ratio).

2) A diminution of free ATP energy.

3) An alteration of contractile proprieties.

First, concerning the decrease of $\mathrm{P} / \mathrm{O}_{2}$ ratio, it is hazardous to speculate about the efficiency of oxidative phosphorylation based only on ADP concentration, since the ADP concentration is maintained by other efficient regenerating ATP systems (i.e., $\mathrm{ADP}+\mathrm{CrP} \rightarrow \mathrm{Cr}+\mathrm{ATP} ; 2 \mathrm{ADP} \rightarrow \mathrm{ATP}+\mathrm{AMP}$ ). It is not possible to exclude the hypothesis of an uncoupling oxidative phosphorylation. Indeed, Russell et al. (4) showed a positive correlation between uncoupling protein-3 (UCP-3) mRNA (the putative function of UCP-3 protein is to uncouple oxidative phosphorylation) and the relative slow component of oxygen uptake.

Second, as mentioned by the authors, a decrease in the Gibbs free energy of ATP hydrolysis could explain a part of the fall of observed force since the energy state of the cell can fall during heavy or severe exercise. On the basis of the data reported by Grassi et al. (3), we tested this hypothesis. The classical equation of Gibbs free energy of ATP hydrolysis

Address for reprint requests and other correspondence: F. Borrani, Sport and Exercise Science, The Univ. of Auckland, Private Bag 92019, Auckland Mail Centre 1142 (e-mail: f.borrani@auckland.ac.nz). expressed a function of ADP, Pi, and ATP concentrations has been used (5). A value near 10\% was obtained for the change of Gibbs free energy between rest and the end of the contractions. This result could explain about one-half of the pseudo slow component magnitude.

Finally, the diminution of force production could be linked to the alteration of contractile properties. It is interesting to note that their Fig. $2 C$ shows that the kinetics of the peak force and of the force-time expressed as a percentage of the values determined during the first contraction have a different kinetics. This means that the shape is changing and, more specifically, the base of the shape is widening with fatigue. This widening could be caused by an increase in contraction time and/or time of relaxation. It is interesting to note that these changes in characteristics are usually described in a fatigue condition as a clear case of contractile properties alteration (2).

Let's come back to the "real" slow component. A constant output power in presence of increase oxygen consumption. As mentioned by the authors, it is a sort of "mirror image" of the slow component-like response. Both situations have a common denominator, which is a decrease in efficiency of muscle contraction. Thus the putative mechanisms are identical. Now, to maintain the same output power when there is a decrease in muscle efficiency, the unique solution is a recruitment of additional motor units (1). Thus the interpretation of the authors that the reduced efficiency of muscle contraction, putative mechanism responsible for the slow component, is not necessarily related to a progressive recruitment of muscle fibers, seems questionable.

\section{REFERENCES}

1. Burnley M, Doust JH, Ball D, Jones AM. Effects of prior heavy exercise on $\mathrm{V}_{2}$ kinetics during heavy exercise are related to changes in muscle activity. J Appl Physiol 93: 167-174, 2002.

2. Gilai A, Kirsch GE. Latency-relaxation in single muscle fibres. J Physiol 282: 197-205, 1978.

3. Grassi B, Hogan MC, Greenhaff PL, Hamann JJ, Kelley KM, Aschenbach WG, Constantin-Teodosiu D, Gladden LB. Oxygen uptake onkinetics in dog gastrocnemius in situ following activation of pyruvate dehydrogenase by dichloroacetate. J Physiol 538: 195-207, 2002.

4. Russell A, Wadley G, Snow R, Giacobino JP, Muzzin P, Garnham A, Cameron-Smith D. Slow component of $\mathrm{VO}_{2}$ kinetics: the effect of training status, fibre type, UCP3 mRNA and citrate synthase activity. Int $J$ Obes Relat Metab Disord 26: 157-164, 2002.

5. Smith NP, Barclay CJ, Loiselle DS. The efficiency of muscle contraction. Prog Biophys Mol Biol 88: 1-58, 2005.

6. Zoladz JA, Gladden LB, Hogan MC, Nieckarz Z, Grassi B. Progressive recruitment of muscle fibers is not necessary for the slow component of VO2 kinetics. J Appl Physiol 105: 575-580, 2008. 